\title{
ANALISA PENGARUH PENGETAHUAN DAN PEMAHAMAN TENTANG PERATURAN PERPAJAKAN DAN PERSEPSI YANG BAIK ATAS EFEKTIFITAS SISTEM PERPAJAKAN TERHADAP KEMAUAN MEMBAYAR PAJAK DENGAN KESADARAN MEMBAYAR PAJAK SEBAGAI VARIABEL MEDIASI
}

\author{
Raynaldi Daeng Kuma \\ Program Studi Magister Akuntansi, Universitas Tarumanagara Jakarta \\ Email: raynaldidk@gmail.com
}

Masuk : 30-03-2019, revisi: 25-08-2019, diterima untuk diterbitkan : 30-10-2019

\begin{abstract}
ABSTRAK
Salah satu yang mempengaruhi kepatuhan pajak adalah kemauan membayar pajak, jika kemauan membayar pajak rendah, maka kepatuhan pajak juga akan rendah. Kesadaran menjadi salah faktor yang mempengaruhi kemauan membayar pajak, dan kesadaran wajib pajak akan meningkat jika pengetahuan dan pemahaman tentang peraturan perpajakan serta persepsi yang baik atas efektifitas sistem perpajakan juga meningkat. Dengan demikian, penulis membangun hipotesis dalam penelitian ini yaitu pengaruh pengetahuan dan pemahaman tentang peraturan perpajakan terhadap kesadaran membayar pajak, pengaruh pengetahuan dan pemahaman tentang peraturan perpajakan terhadap kemauan membayar pajak, pengaruh persepsi yang baik atas efektifitas sistem perpajakan terhadap kesadaran memabayar pajak, pengaruh persepsi yang baik atas efektifitas sistem perpajakan terhadap kemauan membayar pajak, pengaruh kesadaran membayar pajak terhadap kemauan membayar pajak, pengaruh kesadaran membayar pajak sebagai variabel mediasi antara pengetahuan dan pemahaman tentang peraturan perpajakan terhadap kemauan membayar pajak, serta pengaruh kesadaran membayar pajak sebagai variabel mediasi antara persepsi yang baik atas efektifitas sistem perpajakan terhadap kemauan membayar pajak. Jumlah sampel yang digunakan untuk diolah sebanyak 100 tanggapan, dan data tersebut diolah dengan metode SEM (Structural Equation Model) dengan program SmartPLS 3. Dalam uji hipotesis, pengaruh pengetahuan dan pemahaman tentang peraturan perpajakan terhadap kesadaran membayar pajak adalah signifikan dan positif, pengaruh pengetahuan dan pemahaman tentang peraturan perpajakan terhadap kemauan membayar pajak adalah signifikan dan positif, pengaruh persepsi yang baik atas efektifitas sistem perpajakan terhadap kesadaran memabayar pajak adalah tidak signifikan, pengaruh persepsi yang baik atas efektifitas sistem perpajakan terhadap kemauan membayar pajak adalah signifikan dan positif, pengaruh kesadaran membayar pajak terhadap kemauan membayar pajak adalah tidak signifikan, pengaruh kesadaran membayar pajak sebagai variabel mediasi antara pengetahuan dan pemahaman tentang peraturan perpajakan terhadap kemauan membayar pajak adalah tidak signifikan dan kesadaran membayar pajak tidak dapat menjadi mediasi antara kedua variabel tersebut, pengaruh kesadaran membayar pajak sebagai variabel mediasi antara persepsi yang baik atas efektifitas sistem perpajakan terhadap kemauan membayar pajak adalah tidak signifikan dan kesadaran membayar pajak tidak dapat menjadi mediasi antara kedua variabel tersebut.
\end{abstract}

Kata Kunci: Pengetahuan dan pemahaman tentang peraturan perpajakan, persepsi yang baik atas efektifitas system perpejakan, kesadaran membayar pajak, dan kemauan membayar pajak.

\section{ABSTRACT}

One that affects tax compliance is the willingness to pay taxes, if the willingness to pay taxes is low, then tax compliance will also be low. Awareness becomes one of the factors that influence the willingness to pay taxes, and awareness of taxpayers will increase if the knowledge and understanding of tax regulations and a good perception of the effectiveness of the taxation system also increases. Thus, the authors build a hypothesis in this study that is the influence of knowledge and understanding of tax regulations on the awareness of paying taxes, the influence of knowledge and understanding of tax regulations on the willingness to pay taxes, the effect of good perceptions on the effectiveness of the taxation system on the awareness of paying taxes, the influence of perception both the effectiveness of the taxation system on the willingness to pay taxes, the effect of awareness of paying taxes on the willingness to pay taxes, the effect of awareness of paying taxes as a mediating variable between knowledge and understanding of tax regulations on the willingness to pay taxes, and the effect of awareness of paying taxes as a 
mediating variable between good perceptions for the effectiveness of the taxation system against the willingness to pay taxes. The number of samples used to be processed was 100 responses, and the data was processed using the SEM (Structural Equation Model) method with the SmartPLS 3 program. In the hypothesis test, the effect of knowledge and understanding of tax regulations on tax paying awareness is significant and positive, the effect of knowledge and understanding of tax regulations on tax payers is significant and positive, the effect of good perceptions on the effectiveness of the tax system on awareness of paying tax is not significant, the effect of a good perception of the effectiveness of the taxation system on the willingness to pay taxes is significant and positive, the effect of awareness of paying taxes on the willingness to pay taxes is not significant, the effect of awareness of paying taxes as a mediating variable between knowledge and understanding of taxation regulations on the willingness to pay taxes is insignificant and awareness of paying taxes cannot be a mediator between the two variables, the effect of awareness of paying taxes as a mediating variable between good perceptions of the effectiveness of the tax system The willingness to pay taxes is insignificant and awareness of paying taxes cannot be a mediator between the two variables.

Keywords: Knowledge and understanding of tax regulations, a good perception of the effectiveness of the tax system, awareness of paying taxes, and willingness to pay taxes.

\section{PENDAHULUAN}

\section{Latar Belakang}

Setiap negara membutuhkan dana yang besar untuk terus membangun infrastrukturnya. Tiba saat dimana sumber daya sudah tidak mampuni dalam menopang pendapatan Negara, terdapat satu sektor yang memiliki umur yang tidak terhingga dalam menopang kebutuhan dana untuk Negara, sektor tersebut adalah perpajakan (Widayati dan Nurlis, 2010). Pentingnya Pajak di Negara Indonesia tidak didukung dengan kepatuhan oleh wajib pajak. Menteri Keuangan Sri Mulyani (2017) menyatakan bahwa tingkat kepatuhan pajak di negara Indonesia masih tergolong rendah. Pernyataan itu disertai penjelasan bahwa standard rasio pajak adalah $15 \%$ sedangkan di Indonesia rasio pajak masih $12 \%$. Pernyataan yang hampir serupa juga diutarakan oleh Direktur Eksekutif Center for Indonesia Taxation Analysis (CITA) Yustinus Prastowo yang menilai bahwa tingkat kepatuhan masyarakat Indonesia akan pajak masih tergolong rendah.

Fikriningrum dan Muchamad (2012) menegaskan bahwa kepatuhan wajib pajak juga membutuhkan kemauan dari wajib pajak itu sendiri. Aruan et al (2017) menyatakan dalam penelitiannya bahwa salah satu variabel yang mempengaruhi kepatuhan adalah kemauan membayar pajak. Pengaruh dari kemauan membayar pajak terhadap kepatuhan pajak adalah signifikan dan positif. Jika tingkat kemauan membayar pajak itu rendah, maka tingkat kepatuhan pajak juga menurun.

Widayati dan Nurlis (2010) menyatakan bahwa kurangnya tingkat kemauan membayar pajak salah satunya disebabkan adanya asas perpajakan, yaitu hasil pajak yang dibayarkan oleh wajib pajak tidak akan dinikmati secara langsung oleh wajib pajak. Dengan demikian dibutuhkan kesadaran wajib pajak untuk menyadari bahwa jalan raya, pusat kesehatan, pemerataan pendidikan, dan fasilitas umum lainnya adalah hasil dari pembayaran pajak yang wajib pajak bayarkan.

Dalam penelitian Nugroho dan Zulaikha (2012), mereka menyatakan bahwa terdapat beberapa faktor yang mempengaruhi rendahnya kesadaran membayar pajak, yaitu; kurangnya pengetahuan dan pemahaman mengenai peraturan perpajakan, serta persepsi yang buruk terhadap efektifitas sistem perpajakan. 
Menurut Munawaroh et al (2014) mengartikan bahwa persepsi yang baik atas efektivitas sistem perpajakan yaitu pandangan wajib pajak terhadap sistem perpajakan yang efektif dan memudahkan setiap wajib pajak dalam melakukan kewajiban perpajakannya. Lovihan (2014) menyatakan mengenai pengetahuan dan pemahaman tentang peraturan perpajakan adalah sebuah cara bagi wajib pajak untuk memahami peraturan perpajakan yang sedang berlaku. Cara memahami bisa didapat melalui Pendidikan formal maupun informal.

\section{Rumusan Masalah}

Berdasarkan hal-hal yang telah dipaparkan diatas, maka rumusan masalahnya dalam penelitian ini adalah:

1. Apakah pengetahuan dan pemahaman tentang peraturan perpajakan berpengaruh terhadap kesadaran membayar pajak?

2. Apakah persepsi yang baik atas efektifitas sistem perpajakan berpengaruh terhadap kesadaran membayar pajak?

3. Apakah pengetahuan dan pemahaman tentang peraturan perpajakan berpengaruh terhadap kemauan membayar pajak?

4. Apakah persepsi yang baik atas efektifitas sistem perpajakan berpengaruh terhadap kemauan membayar pajak?

5. Apakah kesadaran membayar pajak berpengaruh terhadap kemauan membayar pajak?

6. Apakah kesadaran membayar pajak dapat memediasi pengetahuan dan pemahaman tentang peraturan perpajakan dan persepsi yang baik atas efektifitas sistem perpajakan terhadap kemauan membayar pajak?

\section{METODE PENELITIAN}

Penentuan sampel dalam penelitian ini dikenal dengan istilah purposive random sampling atau pengambilan sampel secara acak. Purposive random sampling diterapkan untuk melakukan proses pemilihan sampel. Dengan diterapkannya sistem purposive random sampling, maka setiap wajib pajak yang tinggal didaerah Gading Serpong, Alam Sutera, Bumi Serpong Damai, dan Karawaci akan berhak untuk memiliki kesempatan dalam mengambil bagian untuk menjadi sampel penelitian ini (Sekaran dan Roger, 2013; 247).

\section{Operasional Variabel}

1. Kemauan Membayar Pajak

Kemauan membayar pajak bisa berarti sebagai suatu nilai yang rela untuk dikorbankan oleh seseorang (yang diatur dalam peraturan perundang-undangan) dan dipergunakan dalam membayar dan memenuhi kebutuhan negara dan orang tersebut tidak mendapatkan barang atau jasa lain sebagai kontraprestasi secara langsung (Rantung dan Priyo, 2009).

2. Kesadaran Membayar Pajak

Menurut Nugroho dan Zulaikha (2012), kesadaran wajib pajak dalam melakukan pembayaran pajak terhutangnya memiliki arti, kondisi saat wajib pajak tersebut memahami, mengetahui, dan juga mengerti mengenai tata cara untuk melakukan tanggung jawab perpajakannya.

3. Pengentahuan dan Pemahaman Tentang Peraturan Perpajakan.

Resmi (2009) dalam Nugroho dan Zulaikha (2012), pengetahuan dan pemahaman tentang peraturan perpajakan adalah sebuah proses ketika wajib pajak dapat mengetahui berbagai hal 
mengenai pajak dan pengaplikasian pengetahuan tersebut dalam tindakan, salah satunya dalam membayar pajaknya.

\section{Persepsi yang Baik Atas Efektifitas Sistem Perpajakan}

Nugroho dan Zulaikha (2012) menjelaskan bahwa persepsi wajib pajak terhadap sistem perpajakan akan berkaitan dengan sistem yang mereka gunakan untuk melakukan tanggungjawab perpajakannya. Jika mereka mencoba sistem perpajakan sekarang ini dan merasa sistem tersebut dapat dipercaya, akurat, dan juga handal, maka pandangan mereka terhadap sistem tersebut akan menjadi positif dan mereka akan mau untuk sadar dalam membayar pajaknya.

\section{Structural Equation Model (SEM)}

Dalam Sholihin dan Dwi (2013; 2-4) menyatakan bahwa SEM adalah salah satu jenis dari analisis multivariat (multivariat analysis) yang digunakan dalam ilmu sosial. Analisis multivariat merupakan sebuah aplikasi dalam metode statistika yang bertujuan untuk menganalisis beberapa variabel penelitian secara serempak atau simultan. Mereka juga menyatakan bahwa SEM memiliki kelebihan utama yaitu analisis ini tetap mampu menguji model penelitian walaupun cukup kompleks secara serempak atau simultan, selain itu juga SEM mampu menganalisis variabel yang tidak dapat diukur secara langsung (unobserved variables) dan juga memperhitungkan kesalahan pengukurannya.

1. Pengujian Outer Model atau Evaluasi Model Pengukuran.

Ghozali dan Hengky (2015) menjelaskan bahwa evaluasi Outer Model atau model pengukuran dilakukan untuk menilai validitas dan reliabilitas dari model yang ada. Tipe model pengukuran yang digunakan oleh peneliti dalam penelitian ini adalah outer model dengan indikator reflektif. Pengujian yang akan dilakukan adalah pengujian validitas dan reliabilitas. Dengan tujuan untuk memperoleh hasil, peneliti akan menggunakan metode analisis algorithm dan software yang digunakan adalah SmartPLS. Alat ukur yang digunakan dalam penelitian ini menggunakan reliability, convergent validity, dan discriminant validity.

\section{Composite Reliability dan Convergent Validity (Variabel Laten)}

\begin{tabular}{|c|c|c|c|c|}
\hline & Cronbach's Alpha & rho_A & Composite Reliability & Average Varian... \\
\hline KEMAUAN & 0.836 & 0.857 & 0.880 & 0.552 \\
\hline KESADARAN & 0.863 & 0.876 & 0.898 & 0.596 \\
\hline PENGETAHUA... & 0.845 & 0.848 & 0.886 & 0.566 \\
\hline SISTEM PERPAJ... & 0.896 & 0.904 & 0.921 & 0.662 \\
\hline
\end{tabular}

(Sumber: Olah Data Penulis, 2019)

Melalui tabel 1 yang berada diatas, maka dapat diambil kesimpulan bahwa seluruh konstruk variabel laten dinyatakan reliabel, karena nilai Cronbach's Alpha dari setiap konstruk variabel laten adalah $0.836,0.863,0.845$, dan 0.896 yaitu nilainya lebih dari 0.70 , dan juga dapat dilihat nilai Composite Reliability dari setiap konstruk variabel laten adalah 0.880, 0.898, 0.886, dan 0.921 yaitu nilainya lebih dari 0.70 .

Selain itu, melalui tabel 1 juga dapat diambil kesimpulan bahwa konstruk variabel laten dinyatakan valid, karena nilai AVE (Average Variance Extracred) dari setiap konstruk variabel laten adalah $0.552,0.596,0.566$, dan 0.662 yaitu nilainya lebih dari 0.50 . 


\section{Convergent Validity}

Berdasarkan hasil dibawah, dapat ditarik kesimpulan bahwa besarnya pengaruh wajib pajak mengetahui dan memahami mengenai Pendapatan Tidak Kena Pajak (PTKP), Pendapatan Kena Pajak (PKP) dan Tarif Pajak dan pelaporan pajak melalui e-SPT dan e-Filling memudahkan wajib pajak dalam melaporkan pajak adalah hal yang memiliki pengaruh terbesar pada kemauan wajib pajak dalam membayar pajak.

Berikutnya, besarnya pengaruh wajib pajak sadar bahwa pajak yang telah mereka bayarkan dapat digunakan untuk menunjang pembangunan negara memiliki pengaruh terbesar terhadap kemauan membayar pajak, artinya adalah kesadaran wajib pajak terhadap penggunaan pajak yang mereka bayarkan untuk menunjang pembangunan negara akan meningkatkan kemauan wajib pajak dalam membayar pajak.

Selain itu juga dapat disimpulkan bahwa besarnya pengaruh perilaku wajib pajak dalam membayar pajak dapat terlihat dari wajib pajak yang menyiapkan dokumen yang diperlukan untuk membayar pajak, beberapa hal diatas merupakan persepsi wajib pajak yang tinggal didaerah Gading Serpong, Alam Sutera, Bumi Serpong Damai, dan Karawaci dalam kemauan mereka dalam membayar pajak.

Tabel 2. Tabel Outer Loading

\begin{tabular}{|c|c|c|c|c|}
\hline Indicator & Kemauan Pajak & Kesadaran Pajak & Pengetahuan Pajak & Sistem Pajak \\
\hline KMAU1 & 0.806 & & & \\
\hline KMAU2 & 0.766 & & & \\
\hline KMAU3 & 0.831 & & & \\
\hline KMAU4 & 0.585 & & & \\
\hline KMAU5 & 0.710 & & & \\
\hline KMAU6 & 0.736 & & & \\
\hline KSDR1 & & 0.748 & & \\
\hline KSDR2 & & 0.650 & & \\
\hline KSDR3 & & 0.801 & & \\
\hline KSDR4 & & 0.866 & & \\
\hline KSDR5 & & 0.786 & & \\
\hline KSDR6 & & 0.763 & & \\
\hline TAHU1 & & & 0.678 & \\
\hline TAHU2 & & & 0.780 & \\
\hline TAHU3 & & & 0.854 & \\
\hline TAHU4 & & & 0.908 & \\
\hline TAHU5 & & & 0.872 & \\
\hline TAHU6 & & & 0.770 & \\
\hline SIST1 & & & & 0.649 \\
\hline SIST2 & & & & 0.776 \\
\hline SIST3 & & & & 0.794 \\
\hline SIST4 & & & & 0.769 \\
\hline SIST5 & & & & 0.780 \\
\hline SIST6 & & & & 0.737 \\
\hline
\end{tabular}

(Sumber: Olah Data Penulis, 2019) 
Discriminant Validity

Berdasarkan tabel 3 yang berada dibawah, maka dapat dilihat bahwa nilai korelasi antar indikator dengan variabel latennya lebih besar dibandingkan dengan indikator tersebut terhadap variabel laten lainnya. Hal ini menyatakan bahwa model yang ada memiliki Discriminant Validity yang baik, dan dari hasil tersebut dapat diambil kesimpulan bahwa validitas setiap indikator terhadap variabel latennya dinyatakan valid.

Tabel 3. Cross Loading

\begin{tabular}{|l|c|c|c|c|}
\hline Indicator & Kemauan Pajak & Kesadaran Pajak & Pengetahuan Pajak & Sistem Pajak \\
\hline KMAU1 & $\mathbf{0 . 8 0 6}$ & 0.463 & 0.495 & 0.586 \\
\hline KMAU2 & $\mathbf{0 . 7 6 6}$ & 0.244 & 0.430 & 0.447 \\
\hline KMAU3 & $\mathbf{0 . 8 3 1}$ & 0.359 & 0.522 & 0.611 \\
\hline KMAU4 & $\mathbf{0 . 5 8 5}$ & 0.135 & 0.339 & 0.271 \\
\hline KMAU5 & $\mathbf{0 . 7 1 0}$ & 0.248 & 0.331 & 0.463 \\
\hline KMAU6 & $\mathbf{0 . 7 3 6}$ & 0.378 & 0.379 & 0.584 \\
\hline KSDR1 & 0.254 & $\mathbf{0 . 7 4 8}$ & 0.548 & 0.213 \\
\hline KSDR2 & 0.254 & $\mathbf{0 . 6 5 0}$ & 0.346 & 0.352 \\
\hline KSDR3 & 0.353 & $\mathbf{0 . 8 0 1}$ & 0.453 & 0.361 \\
\hline KSDR4 & 0.322 & $\mathbf{0 . 8 6 6}$ & 0.505 & 0.444 \\
\hline KSDR5 & 0.401 & $\mathbf{0 . 7 8 6}$ & 0.657 & 0.457 \\
\hline KSDR6 & 0.370 & $\mathbf{0 . 7 6 3}$ & 0.520 & 0.406 \\
\hline TAHU1 & 0.519 & 0.403 & $\mathbf{0 . 6 4 9}$ & 0.465 \\
\hline TAHU2 & 0.342 & 0.427 & $\mathbf{0 . 7 7 6}$ & 0.372 \\
\hline TAHU3 & 0.479 & 0.545 & $\mathbf{0 . 7 9 4}$ & 0.348 \\
\hline TAHU4 & 0.492 & 0.523 & $\mathbf{0 . 7 6 9}$ & 0.520 \\
\hline TAHU5 & 0.356 & 0.552 & $\mathbf{0 . 7 8 0}$ & 0.332 \\
\hline TAHU6 & 0.345 & 0.545 & $\mathbf{0 . 7 3 7}$ & 0.327 \\
\hline SIST1 & 0.424 & 0.422 & 0.387 & $\mathbf{0 . 6 7 8}$ \\
\hline SIST2 & 0.483 & 0.341 & 0.384 & $\mathbf{0 . 7 8 0}$ \\
\hline SIST3 & 0.597 & 0.385 & 0.438 & $\mathbf{0 . 8 5 4}$ \\
\hline SIST4 & 0.572 & 0.436 & 0.416 & $\mathbf{0 . 9 0 8}$ \\
\hline SIST5 & 0.639 & 0.429 & 0.462 & $\mathbf{0 . 8 7 2}$ \\
\hline SIST6 & 0.597 & 0.374 & 0.477 & $\mathbf{0 . 7 7 0}$ \\
\hline
\end{tabular}

(Sumber: Olah Data Penulis, 2019)

2. Pengujian Inner Model atau Evaluasi Model Struktural

Tujuan dilakukannya evaluasi model struktural (inner model) menurut Ghozali dan Hengky (2015) adalah memprediksi pengaruh antara variabel laten. Alat ukur dengan menggunakan $R$ Square dan Pengujian Hipotesis 
Path Coefficients (Analisis Koefisien Jalur)

Tabel 4. Path Coefficients

\begin{tabular}{|l|c|c|c|c|c|}
\cline { 2 - 6 } \multicolumn{1}{l|}{} & Coefficient & $\begin{array}{c}\text { Sample } \\
\text { Mean }\end{array}$ & $\begin{array}{c}\text { Standard } \\
\text { Deviasi }\end{array}$ & $\begin{array}{c}\text { T } \\
\text { Statistik }\end{array}$ & P Value \\
\hline Pengetahuan Pajak $>$ Kemauan Pajak & 0.310 & 0.336 & 0.108 & 2.868 & 0.002 \\
\hline Pengetahuan Pajak -> Kesadaran Pajak & 0.569 & 0.548 & 0.122 & 4.678 & 0.000 \\
\hline Pengetahuan Pajak -> Kesadaran Pajak > Kemauan Pajak & -0.024 & -0.020 & 0.072 & 0.339 & 0.368 \\
\hline Sistem Pajak -> Kemauan Pajak & 0.543 & 0.519 & 0.105 & 5.150 & 0.000 \\
\hline Sistem Pajak -> Kesadaran Pajak & 0.190 & 0.217 & 0.126 & 1.508 & 0.066 \\
\hline Sistem Pajak -> Kesadaran Pajak-> Kemauan Pajak & -0.008 & -0.007 & 0.030 & 0.273 & 0.392 \\
\hline Kesadaran Pajak -> Kemauan Pajak & -0.043 & -0.035 & 0.123 & 0.348 & 0.364 \\
\hline
\end{tabular}

(Sumber: Olah Data Penulis, 2019

Berdasarkan uji statistic dalam tabel 4 yang berada diatas terdapat 3 jalur yang signifikan. Ketiga jalur tersebut adalah; (1) Pengetahuan dan Pemahaman Tentang Peraturan Perpajakan terhadap Kemauan Membayar Pajak (Koefisien $=0.310$ dan T Statistik $=2.868$ ), (2) Pengetahuan dan Pemahaman Tentang Peraturan Perpajakan terhadap Kesadaran Membayar Pajak (Koefisien = 0.569 dan T Statistik = 4.678), (3) Persepsi yang Baik Atas Efektifitas Sistem Perpajakan terhadap Kemauan Membayar Pajak (Koefisien $=0.543$ dan $\mathrm{T}$ Statistik $=5.150$ ). Dalam penelitian ini juga terdapat dua jalur yang tidak signifikan yaitu Persepsi yang Baik Atas Efektifitas Sistem Perpajakan terhadap Kesadaran Membayar Pajak dan Kesadaran Membayar Pajak terhadap Kemauan Membayar Pajak.

Pengujian Pengaruh Tidak Langsung

Dengan hasil pengujian penelitian diatas, dapat dilihat bahwa kesadaran membayar pajak tidak dapat memediasi hubungan antara pengetahuan dan pemahaman tentang peraturan perpajakan dan persepsi yang baik atas efektifitas system perpajakan tehadap kemauan membayar pajak.

\section{$R$-Square}

Tabel 5. Table of R-Square

\begin{tabular}{|c|c|c|}
\hline & R Square & R Square Adjus... \\
\hline KEMAUAN & 0.529 & 0.515 \\
\hline KESADARAN & 0.473 & 0.462 \\
\hline
\end{tabular}

(Sumber: Olah Data Penulis, 2019)

Dari tabel diatas dapat disimpulkan bahwa nilai $R$-Square untuk kemauan membayar pajak adalah 0.529 , itu berarti bahwa sebanyak 52.9\% kemauan membayar pajak dipengaruhi oleh variabel-variabel independen dalam penelitian ini, sedangkan $47.1 \%$ dipengaruhi oleh variabel lain yang tidak diteliti dalam penelitian ini. Sedangkan untuk kesadaran membayar pajak memiliki nilai $R$-Square sebesar 0.473 , yang berarti bahwa sebanyak $47.3 \%$ kesadaran membayar pajak dipengaruhi oleh variabel-variabel independen dalam penelitian ini dan $52.7 \%$ kesadaran membayar pajak dipengaruhi oleh variabel lain yang tidak diteliti dalam penelitian ini. Model ini dapat disimpulkan sebagai model yang moderate karena nilai $R$-Square mendekati 0.5 . 


\section{HASIL DAN PEMBAHASAN}

Tabel 6. Hasil Pengujian Hipotesis

\begin{tabular}{|c|c|c|c|c|}
\hline & Coefficient & $\begin{array}{c}\mathrm{T} \\
\text { Statistik }\end{array}$ & P Value & Hipotesis \\
\hline Pengetahuan Pajak -> Kesadaran Pajak & 0.569 & 4.678 & 0.000 & $\begin{array}{c}\text { H1 tidak } \\
\text { dapat ditolak }\end{array}$ \\
\hline Sistem Pajak -> Kesadaran Pajak & 0.190 & 1.508 & 0.066 & $\mathrm{H} 2$ ditolak \\
\hline Pengetahuan Pajak -> Kemauan Pajak & 0.310 & 2.868 & 0.002 & $\begin{array}{c}\text { H3 tidak } \\
\text { dapat ditolak }\end{array}$ \\
\hline Sistem Pajak -> Kemauan Pajak & 0.543 & 5.150 & 0.000 & $\begin{array}{c}\text { H4 tidak } \\
\text { dapat ditolak }\end{array}$ \\
\hline Kesadaran Pajak -> Kemauan Pajak & -0.043 & 0.348 & 0.364 & H5 ditolak \\
\hline Pengetahuan Pajak -> Kesadaran Pajak -> Kemauan Pajak & -0.024 & 0.339 & 0.368 & H6 ditolak \\
\hline Sistem Pajak -> Kesadaran Pajak-> Kemauan Pajak & -0.008 & 0.273 & 0.392 & H7 ditolak \\
\hline
\end{tabular}

(Sumber: Olah Data Penulis, 2019)

Hipotesis 1: Pengetahuan dan pemahaman tentang peraturan perpajakan berpengaruh positif terhadap kemauan membayar pajak.

Dalam tabel 6 diatas menunjukan bahwa nilai koefisien jalur dan t statistik dari konstruk pengetahuan dan pemahaman tentang peraturan perpajakan terhadap kemauan membayar pajak adalah 0.310 dan 2.868. Jika nilai t statistik dan t tabel dibandingkan, maka hasil dari t statistik lebih besar dibandingkan $\mathrm{t}$ tabel, dengan demikian dinyatakan bahwa koefisien jalur tersebut signifikan, selain itu jika nilai $p$-value sebesar 0.002 lebih kecil dibandingkan dengan tingkat error yaitu sebesar 0.050, maka dapat dinyatakan bahwa koefisien jalur tersebut signifikan, dan juga dengan melihat dari nilai koefisien jalur, maka dapat dinyatakan juga bahwa pengaruh yang diberikan oleh variabel eksogen terhadap endogen adalah positif. Kesimpulannya adalah pengaruh pengetahuan dan pemahaman tentang peraturan perpajakan terhadap kemauan membayar pajak adalah signifikan dan berpengaruh positif. Dengan ini dinyatakan bahwa H1 tidak dapat ditolak.

Hipotesis 2: Persepsi yang baik atas efektifitas sistem perpajakan berpengaruh positif terhadap kemauan membayar pajak.

Dalam tabel 6 diatas menunjukan bahwa nilai koefisien jalur dan t statistik dari konstruk persepsi yang baik atas efektifitas sistem perpajakan terhadap kemauan membayar pajak adalah 0.543 dan 5.150. Jika nilai $\mathrm{t}$ statistik dan $\mathrm{t}$ tabel dibandingkan, maka hasil dari $\mathrm{t}$ statistik lebih besar dibandingkan $t$ tabel, dengan demikian dinyatakan bahwa koefisien jalur tersebut signifikan, selain itu jika nilai $p$-value sebesar 0.000 lebih kecil dibandingkan dengan tingkat error yaitu sebesar 0.050, maka dapat dinyatakan bahwa koefisien jalur tersebut signifikan, dan juga dengan melihat dari nilai koefisien jalur, maka dapat dinyatakan juga bahwa pengaruh yang diberikan oleh variabel eksogen terhadap endogen adalah positif. Kesimpulannya adalah pengaruh persepsi yang baik atas efektifitas sistem perpajakan terhadap kemauan membayar pajak adalah signifikan dan berpengaruh positif. Dengan ini dinyatakan bahwa H2 tidak dapat ditolak.

Hipotesis 3: Pengetahuan dan pemahaman tentang peraturan perpajakan berpengaruh positif terhadap kesadaran membayar pajak.

Dalam tabel 6 diatas menunjukan bahwa nilai koefisien jalur dan t statistik dari konstruk pengetahuan dan pemahaman tentang peraturan perpajakan terhadap kesadaran membayar pajak adalah 0.569 dan 4.678. Jika nilai t statistik dan $\mathrm{t}$ tabel dibandingkan, maka hasil dari t statistik 
lebih besar dibandingkan $\mathrm{t}$ tabel, dengan demikian dinyatakan bahwa koefisien jalur tersebut signifikan, selain itu jika nilai p-value sebesar 0.000 lebih kecil dibandingkan dengan tingkat error yaitu sebesar 0.050, maka dapat dinyatakan bahwa koefisien jalur tersebut signifikan, dan juga dengan melihat dari nilai koefisien jalur, maka dapat dinyatakan juga bahwa pengaruh yang diberikan oleh variabel eksogen terhadap endogen adalah positif. Kesimpulannya adalah pengaruh pengetahuan dan pemahaman tentang peraturan perpajakan terhadap kesadaran membayar pajak adalah signifikan dan berpengaruh positif. Dengan ini dinyatakan bahwa H3 tidak dapat ditolak.

Hipotesis 4: Persepsi yang baik atas efektifitas sistem perpajakan berpengaruh positif terhadap kesadaran membayar pajak.

Dalam tabel 6 diatas menunjukan bahwa nilai koefisien jalur dan t statistik dari konstruk persepsi yang baik atas efektifitas sistem perpajakan terhadap kesadaran membayar pajak adalah 0.190 dan 1.508. Jika nilai t statistik dan $\mathrm{t}$ tabel dibandingkan, maka hasil dari t statistik lebih kecil dibandingkan $\mathrm{t}$ tabel, dengan demikian dinyatakan bahwa koefisien jalur tersebut tidak signifikan, selain itu jika nilai $p$-value sebesar 0.066 lebih besar dibandingkan dengan tingkat error yaitu sebesar 0.050, maka dapat dinyatakan bahwa koefisien jalur tersebut tidak signifikan. Kesimpulannya adalah pengaruh persepsi yang baik atas efektifitas sistem perpajakan terhadap kesadaran membayar pajak adalah tidak signifikan. Dengan ini dinyatakan bahwa H4 ditolak.

Hipotesis 5: Kesadaran membayar pajak berpengaruh positif terhadap kemauan membayar pajak.

Dalam tabel 6 diatas menunjukan bahwa nilai koefisien jalur dan t statistik dari konstruk kesadaran membayar pajak terhadap kemauan membayar pajak adalah -0.043 dan 0.348. Jika nilai $\mathrm{t}$ statistik dan $\mathrm{t}$ tabel dibandingkan, maka hasil dari t statistik lebih kecil dibandingkan $\mathrm{t}$ tabel, dengan demikian dinyatakan bahwa koefisien jalur tersebut tidak signifikan, selain itu jika nilai p-value sebesar 0.364 lebih besar dibandingkan dengan tingkat error yaitu sebesar 0.050 , maka dapat dinyatakan bahwa koefisien jalur tersebut tidak signifikan. Kesimpulannya adalah pengaruh kesadaran membayar pajak terhadap kemauan membayar pajak adalah tidak signifikan. Dengan ini dinyatakan bahwa $\mathbf{H 5}$ ditolak.

Hipotesis 6: Kesadaran membayar pajak dapat memediasi antara pengetahuan dan pemahaman tentang peraturan perpajakan terhadap kemauan membayar pajak.

Dalam tabel 6 diatas menunjukan bahwa nilai koefisien jalur dan t statistik dari konstruk kesadaran membayar pajak dapat memediasi antara pengetahuan dan pemahaman tentang peraturan perpajakan terhadap kemauan membayar pajak adalah -0.024 dan 0.339 . Jika nilai $\mathrm{t}$ statistik dan $\mathrm{t}$ tabel dibandingkan, maka hasil dari t statistik lebih kecil dibandingkan $\mathrm{t}$ tabel, dengan demikian dinyatakan bahwa koefisien jalur tersebut tidak signifikan, selain itu jika nilai p-value sebesar 0.368 lebih besar dibandingkan dengan tingkat error yaitu sebesar 0.050, maka dapat dinyatakan bahwa koefisien jalur tersebut tidak signifikan. Kesimpulannya adalah pengaruh kesadaran membayar pajak dapat memediasi antara pengetahuan dan pemahaman tentang peraturan perpajakan terhadap kemauan membayar pajak adalah tidak signifikan. Dengan ini dinyatakan bahwa H6 ditolak.

Hipotesis 7: Kesadaran membayar pajak dapat memediasi antara persepsi yang baik atas efektifitas sistem perpajakan dengan kemauan membayar pajak. 
Dalam tabel 6 diatas menunjukan bahwa nilai koefisien jalur dan t statistik dari konstruk kesadaran membayar pajak dapat memediasi antara persepsi yang baik atas efektifitas sistem perpajakan dengan kemauan membayar pajak adalah -0.008 dan 0.273 . Jika nilai $t$ statistik dan $t$ tabel dibandingkan, maka hasil dari t statistik lebih kecil dibandingkan $t$ tabel, dengan demikian dinyatakan bahwa koefisien jalur tersebut tidak signifikan, selain itu jika nilai $p$-value sebesar 0.392 lebih besar dibandingkan dengan tingkat error yaitu sebesar 0.050, maka dapat dinyatakan bahwa koefisien jalur tersebut tidak signifikan. Kesimpulannya adalah pengaruh kesadaran membayar pajak dapat memediasi antara persepsi yang baik atas efektifitas sistem perpajakan dengan kemauan membayar pajak adalah tidak signifikan. Dengan ini dinyatakan bahwa H7 ditolak.

\section{KESIMPULAN DAN SARAN}

\section{Kesimpulan}

Dalam 7 Hipotesis yang terdapat dalam penelitian ini, terdapat 3 hipotesis yang tidak ditolak, yaitu; pengaruh antara pengetahuan dan pemahaman tentang peraturan perpajakan terhadap kesadaran membayar pajak, pengaruh antara pengetahuan dan pemahaman tentang peraturan perpajakan terhadap kemauan membayar pajak, dan engaruh antara persepsi yang baik atas efektifitas sistem perpajakan terhadap kemauan membayar pajak.

\section{Saran}

Melalui penelitian ini, peneliti dapat memberikan saran dan masukan kepada beberapa pihak mengenai hasil evaluasi yang bermanfaat kepada beberapa pihak yang memiliki kepentingan dalam penelitian ini:

1. Bagi Diretorat Jenderal Pajak (DJP)

1) Pengatahuan dan Pemahaman Tentang Peraturan Perpajakan

Melalui penelitian ini, DJP diharapkan lebih fokus lagi mencari cara dalam meningkatan pengetahuan dan juga pemahaman tentang peraturan perpajakan bagi wajib pajak. Melalui penelitian ini kemauan wajib pajak dalam membayar pajak akan meningkat apabila pengetahuan dan pemahaman mengenai peraturan perpajakan meningkat. Peneliti memberi beberapa saran, cara untuk meningkatkan pengetahuan dan juga pemahaman peraturan perpajakan bagi wajib pajak.

a) Dengan melakukan sosialisasi tentang peraturan perpajakan. Melaui sosialisasi ini wajib pajak dapat lebih mudah menangkap maksud dari peraturan perpajakan dan akan lebih update jika terdapat perubahan peraturan.

b) Meningkatkan pelayanan melalui customer services. Peningkatan pelayanan customer services dalam kring pajak akan sangat menolong wajib pajak dalam perihal bertanya mengenai peraturan yang ada.

c) Website www.pajak.go.id lebih ditata. Melalui website pajak, wajib pajak lebih mudah untuk mengakses peraturan perpajakan serta lebih cepat mendapatkan informasi mengenai perubahan peraturan perpajakan. Lebih baik lagi jika website pajak ditambahkan fitur chat langsung. Jadi saat wajib pajak membaca peraturan perpajakan dan kurang dimengerti, wajib pajak dapat langsung bertanya pada customer services melalui fitur tersebut.

d) DJP juga dapat meningkatkan pengetahuan dan pemahaman wajib pajak melalui media social yang ada. Saat ini pengguna media sosial sangat banyak, dan jika dimaksimalkan oleh DJP, hal tersebut akan menolong wajib pajak dalam kemudahan mencari, membagi, dan mengetahui info mengenai peraturan perpajakan. 


\section{2) Persepsi yang Baik Atas Efektifitas Sistem Perpajakan}

Melalui penelitian ini DJP diharapkan terus mengembangkan sistem perpajakan untuk membuat wajib pajak lebih efektif dalam melakukan kewajiban perpajakannya. Dalam penelitian ini menyatakan bahwa hubungan dari persepsi yang baik atas efektifitas sistem perpajakan terhadap kemauan membayar pajak tidak berpengaruh signifikan, tetapi nilai signifikansinya mendekati kepada pengaruh signifikan. Saran dari peneliti untuk meningkatkan efektifitas sistem perpajakan.

a) Sistem pajak melalui online lebih diperlengkapi dan diperbaiki. Contohnya untuk $e$ filling, wajib pajak yang perlu mengisi SPT 1770 belum dapat melakukan kewajibannya melalui $e$-filling.

b) Sosialisasi sistem perpajakan melalui online. Masih banyak wajib pajak yang belum mengerti mengenai sistem perpajakan melalui online. Hal tersebut terlihat dari padatnya wajib pajak yang masih mendatangi KPP (Kantor Pelayanan Pajak) tempat wajib pajak tersebut terdaftar untuk melakukan kewajiban perpajakannya.

Sistem pajak juga dapat ditingkatkan dengan membuat aplikasi khusus pajak. Disana wajib pajak hanya perlu login menggunakan ID mereka dan dapat mengakses semua peraturan perpajakan yang ada, selain itu mereka juga dapat melakukan kewajiban perpajakan mereka dalam hal membayar dan melapor pajak menggunakan aplikasi tersebut. Lebih baik lagi jika ada fitur pesan tanya jawab secara langsung seperti messanger application yang memudahkan wajib pajak untuk bertanya. Aplikasi tersebut akan lebih baik jika dapat di unduh dengan mudah serta compatible dengan seluruh smart phone.

3) Kesadaran Membayar Pajak

Dari penelitian ini dapat dilihat bahwa kesadaran membayar pajak tidak berpengaruh signifikan terhadap kemauan membayar pajak, namun pemerintah tetap harus berusaha untuk menanamkan nilai kesadaran dalam membayar pajak. Alasan kesadaran membayar pajak tidak berpengaruh signifikan terhadap kemauan membayar pajak walaupun wajib pajak tetap melakukan kewajiban perpajakannya karena, wajib pajak takut untuk dikenakan sanksi yang telah diatur dalam peraturan perpajakan dan juga kebutuhan dalam menjalankan usaha mereka. Peningkatan kesadaran membayar pajak dapat dilakukan dengan pertolongan dari DJP melalui sosialisasi. Sosialisasi tersebut dapat membahas berupa fungsi pajak bagi Negara ini. Selain itu dapat juga dilakukan dengan transparansinya pemasukan dan penggunaan dari pajak tersebut. Setiap wajib pajak dapat melihat penggunaan dan pemasukan dari pajak yang mereka bayarkan dan dapat sadar bahwa pajak yang mereka bayarkan berguna bagi pembangunan Negara. Terlebih saat program pemerintah yang ada sekarang ini baik, maka wajib pajak dapat langsung melihat kegunaan dari pajak yang mereka bayarkan. Walaupun tidak mendapat kontraprestasi secara langsung.

Selain itu peningkatan kesadaran membayar pajak juga dapat dipengaruhi oleh sanksi yang ada. Sanksi yang telah diatur dalam undang-undang perpajakan akan mempengaruhi wajib pajak dalam membayarkan pajak jika dilakukan dengan tegas dan benar. Sanksi perdapatan berupa denda dan bunga serta sanksi pidana yang bisa berakhir didalam penjara dapat membuat wajib pajak akan sadar pentingnya membayar pajak. Kesadaran juga akan lebih meningkat jika sanksi tersebut lebih ditingkatkan lagi. Peningkatan sanksi berupa bunga dan denda yang lebih tinggi juga dapat mendorong wajib pajak melakukan 
kewajiban perpajakannya dengan benar. Sekaligus dapat meningkatan pendapatan Negara jika ada wajib pajak yang masih tidak patuh.

Kesadaran membayar pajak juga dapat meningkat dengan cara yang sederhana berupa рор up message. Pesan yang muncul saat masyarakat mengakses satu hal melalui internet ataupun di advertising yang berada di berbagai tempat. Pesan yang muncul bisa berisi quotation singkat yang dapat memotivasi masyarakat dalam melakukan kewajiban perpajakannya. Misalkan quote "Orang bijak bayar pajak", walaupun dengan singkat itu, orang-orang dapat tergerak dalam kesadaran mereka membayar pajak.

Usaha untuk meningkatkan kesadaran membayar pajak yang telah berlaku saat ini adalah inklusi kesadaran pajak. Dengan memasukan unsur-unsur agar masyarakat mengetahui mengenai pentingnya membayar pajak kedalam buku ataupun dalam pengajaran. Walaupun melalui penelitian ini pengaruh kesadaran membayar pajak belum signifikan terhadap kemauan membayar pajak, tetapi inklusi pajak tetap harus ditingkatkan. Peneliti percaya sistem ini adalah investasi jangka panjang dari pemerintah untuk meningkatkan kesadaran pentingnya pajak.

2. Bagi Penelitian Berikutnya

1) Responden

Saya menyarankan untuk penelitian berikutnya dapat menambahkan hal-hal berikut ini:

a) Memperluas daerah pengumpulan sampel.

b) Teknik pengumpulan sampel bisa menggunakan purposive sampling agar lebih terarah dan dapat mewakili populasi yang lebih besar.

c) Cara pengumpulan data responden tidak hanya melalui kuesioner tetapi bisa bersamaan dengan melakukan interview terhadap responden.

d) Diharapkan lebih banyak sampel yang dapat dikumpulkan, untuk lebih mencerminkan keadaan populasi yang sebenarnya.

2) Variabel

Saya menyarankan untuk penelitian berikutnya dapat menambahkan variabel yang lain sebagai model dalam penelitiannya. Karena dapat dilihat nilai r-square yang mewakili nilai dari kemauan membayar pajak dari pengetahuan dan pemahaman tentang peraturan perpajakan sebesar $56.9 \%$, masih terdapat variabel lain yang mempengaruhi kemauan membayar pajak yang tidak diteliti dalam penelitian ini sebesar $43.1 \%$. Variabel yang bisa ditambahkan antara lain; kinerja fiskus (Fauziati dan Arfin, 2015), kondisi keuangan (Sulastri et al, 2016), tingkat kepercayaan terhadap pemerintah dan hukum (Handayani et al, 2012), dan norma moral (Permadi et al, 2013).

\section{Ucapan Terima Kasih}

1. Bapak Dr. Ngadiman, SE., M.Si., Ak., CA., selaku Dosen Pembimbing yang telah memberikan bimbingan, waktu, dan banyak memberikan masukan kepada penulis saat menyusun tesis ini.

\section{REFERENSI}

Aruan, R., Edy, S., \& Ni, L. G. E. S. (2017). PENGARUH SIKAP WAJIB PAJAK, MORAL WAJIB PAJAK DAN KEMAUAN UNTUK MEMBAYAR PAJAK TERHADAP TINGKAT KEPATUHAN WAJIB PAJAK ORANG PRIBADI DI KANTOR 
PELAYANAN PAJAK(KPP) PRATAMA GIANYAR. Jurnal Akuntansi, Universitas Pendidikan Ganesha.

Fauziati, P., \& Arfin, S. (2015). PENGARUH EFEKTIFITAS SISTEM PERPAJAKAN DAN PELAYANAN FISKUS TERHADAP KEMAUAN UNTUK MEMBAYAR PAJAK DENGAN KESADARAN MEMBAYAR PAJAK SEBAGAI VARIABEL INTERVENING. Akuntabilitas Vol. VIII, No. 1. 47-60.

Fikriningrum, W. K., Muchamad, S. (2012). ANALISIS FAKTOR-FAKTOR YANG MEMPENGARUHI WAJIB PAJAK ORANG PRIBADI DALAM MEMENUHI KEWAJIBAN MEMBAYAR PAJAK (Studi Kasus Pada Kantor Pelayanan Pajak Pratama Semarang Candisari). Diponegoro Journal of Accounting; Vol. 1, No. 2. 1-15.

Ghozali, I., \& Hengky, L. (2015). Partial Least Squares, Konsep, Teknik dan Aplikasi Menggunakan Program SmartPLS 3.0 untuk Penelitian Empiris. Semarang: Badan Penerbit Universitas Diponegoro.

Handayani, S. W., AGUS, F., \& UMI, P. (2012). FAKTOR-FAKTOR YANG MEMPENGARUHI KEMAUAN MEMBAYAR PAJAK WAJIB PAJAK ORANG PRIBADI YANG MELAKUKAN PEKERJAAN BEBAS. Simposium Nasional Akuntansi $X V$.

Lovihan, S. (2014). PENGARUH KESADARAN MEMBAYAR PAJAK, PENGETAHUAN DAN PEMAHAMAN PERATURAN PERPAJAKAN, DAN KUALITAS LAYANAN TERHADAP KEMAUAN MEMBAYAR PAJAK WAJIB ORANG PRIBADI DI KOTA TOMOHON. Jurnal Riset Akuntansi dan Auditing; Vol. 5, No. 1.

Munawaroh, S., Haris, W., \& Intan, I. (2014). Faktor-Faktor yang Mempengaruhi Kemauan untuk Membayar Pajak Wajib Pajak Orang Pribadi yang Melakukan Pekerjaan Bebas (Studi Pada KPP Pratama Kota Madiun). Jurnal Riset Manajemen dan Akuntansi; Vol. 2, No. 1. 35-44.

Nugroho, A. N., \& Zulaikha. (2012). FAKTOR-FAKTOR YANG MEMPENGARUHI KEMAUAN UNTUK MEMBAYAR PAJAK DENGAN KESADARAN MEMBAYAR PAJAK SEBAGAI VARIABEL INTERVENING (Studi Kasus Wajib Pajak Orang Pribadi Yang Melakukan Pekerjaan Bebas Yang Terdaftar Di KPP Pratama Semarang Tengah Satu). Diponegoro Journal of Accounting; Vol. 1, No. 2. 1-11.

Permadi, T., Azwir, N., \& Yuneita, A. (2013). STUDI KEMAUAN MEMBAYAR PAJAK PADA WAJIB PAJAK ORANG PRIBADI YANG MELAKUKAN PEKERJAAN BEBAS (Kasus pada KPP Pratama Tampan Pekanbaru). Jurnal Ekonomi; Vol. 21, No. 2.

Rantung, T. V., \& Priyo, H. A. (2009). DAMPAK PROGRAM SUNSET POLICY TERHADAP FAKTOR-FAKTOR YANG MEMPENGARUHI KEMAUAN MEMBAYAR PAJAK (Studi pada Wajib Pajak Orang Pribadi Pelaku Usaha di Wilayah KPP Pratama Salatiga). Simposium Nasional Akuntansi XI.

Sekaran, U., \& Roger, B. (2013). Research Methods for Business (6th Ed). United Kingdom: Wiley.

Sholihin, M., \& Dwi, R. (2013). Analisis SEM-PLS dengan WarpPLS 3.0 untuk Hubungan Nonlinier dalam Penelitian Sosial dan Bisnis. Yogyakarta: Andi.

Sulastri, I. D., Suharno., \& Fadjar, H. (2016). PENGARUH PERSEPSI PENGETAHUAN PERATURAN PAJAK, SISTEM PERPAJAKAN, KESADARAN MEMBAYAR PAJAK, DAN KONDISI KEUANGAN TERHADAP KEMAUAN MEMBAYAR PAJAK PENGHASILAN PADA WAJIB PAJAK. Jurnal Akuntansi dan Sistem Teknologi Informasi; Vol. 12, No. 2.

Widayati., \& Nurlis. (2010). FAKTOR-FAKTOR YANG MEMPENGARUHI KEMAUAN UNTUK MEMBAYAR PAJAK WAJIB PAJAK ORANG PRIBADI YANG 
MELAKUKAN PEKERJAAN BEBAS (STUDI KASUS PADA KPP PRATAMA GAMBIR TIGA). Simposium Nasional Akuntansi XIII.

https://tirto.id/sri-mulyani-masalah-kepatuhan-pajak-ri-masih-menjadi-pr-cQHb diakses pada tanggal 8 Januari 2019 Jam 16.03 WIB. Perihal Sri Mulyani (2017)

https:/finance.detik.com/berita-ekonomi-bisnis/d-4214299/tingkat-kepatuhan-pajak-masyarakatri-masih-rendah diakses pada tanggal 8 Januari 2019 Jam 16.03 WIB. Perihal Yustinus Prastowo. 